\title{
Front Matter: Volume 8689
}

"Front Matter: Volume 8689," Proc. SPIE 8689, Behavior and Mechanics of Multifunctional Materials and Composites 2013, 868901 (7 May 2013); doi: 10.1117/12.2021919

EDIE $\quad$ Event: SPIE Smart Structures and Materials + Nondestructive Evaluation and Health Monitoring, 2013, San Diego, California, United States 


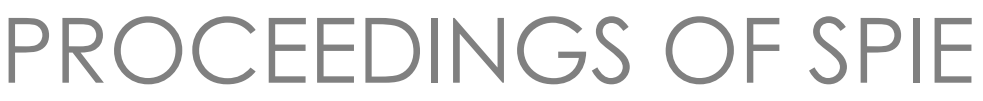

\title{
Behavior and Mechanics of Multifunctional Materials and Composites 2013
}

\author{
Nakhiah C. Goulbourne \\ Hani E. Naguib \\ Editors \\ 10-14 March 2013 \\ San Diego, California, United States \\ Sponsored by \\ SPIE \\ Cosponsored by \\ American Society of Mechanical Engineers (United States) \\ Cooperating Organizations \\ Intelligent Materials Forum (Japan) \\ Jet Propulsion Laboratory (United States) \\ National Science Foundation (United States) \\ Published by \\ SPIE
}

Volume 8689 
The papers included in this volume were part of the technical conference cited on the cover and title page. Papers were selected and subject to review by the editors and conference program committee. Some conference presentations may not be available for publication. The papers published in these proceedings reflect the work and thoughts of the authors and are published herein as submitted. The publisher is not responsible for the validity of the information or for any outcomes resulting from reliance thereon.

Please use the following format to cite material from this book:

Author(s), "Title of Paper," in Behavior and Mechanics of Multifunctional Materials and Composites 2013, edited by Nakhiah C. Goulbourne, Hani E. Naguib, Proceedings of SPIE Vol. 8689 (SPIE, Bellingham, WA, 2013) Article CID Number.

ISSN: 0277-786X

ISBN: 9780819494726

Published by

SPIE

P.O. Box 10, Bellingham, Washington 98227-0010 USA

Telephone +1 3606763290 (Pacific Time) · Fax +1 3606471445

SPIE.org

Copyright @ 2013, Society of Photo-Optical Instrumentation Engineers.

Copying of material in this book for internal or personal use, or for the internal or personal use of specific clients, beyond the fair use provisions granted by the U.S. Copyright Law is authorized by SPIE subject to payment of copying fees. The Transactional Reporting Service base fee for this volume is $\$ 18.00$ per article (or portion thereof), which should be paid directly to the Copyright Clearance Center (CCC), 222 Rosewood Drive, Danvers, MA 01923. Payment may also be made electronically through CCC Online at copyright.com. Other copying for republication, resale, advertising or promotion, or any form of systematic or multiple reproduction of any material in this book is prohibited except with permission in writing from the publisher. The CCC fee code is 0277-786X/13/\$18.00.

Printed in the United States of America.

Publication of record for individual papers is online in the SPIE Digital Library.

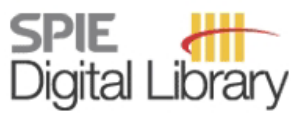

SPIEDigitalLibrary.org

Paper Numbering: Proceedings of SPIE follow an e-First publication model, with papers published first online and then in print and on CD-ROM. Papers are published as they are submitted and meet publication criteria. A unique, consistent, permanent citation identifier (CID) number is assigned to each article at the time of the first publication. Utilization of CIDs allows articles to be fully citable as soon as they are published online, and connects the same identifier to all online, print, and electronic versions of the publication. SPIE uses a six-digit CID article numbering system in which:

- The first four digits correspond to the SPIE volume number.

- The last two digits indicate publication order within the volume using a Base 36 numbering

system employing both numerals and letters. These two-number sets start with 00, 01, 02, 03, 04, $05,06,07,08,09,0 A, 0 B \ldots 0 Z$, followed by 10-1Z, 20-2Z, etc.

The CID Number appears on each page of the manuscript. The complete citation is used on the first page, and an abbreviated version on subsequent pages. Numbers in the index correspond to the last two digits of the six-digit CID Number. 


\section{Contents}

ix Conference Committee

\section{SESSION $1 \quad$ PIEZOELECTRIC COMPOSITES}

868902 Ultra high energy density and fast discharge nanocomposite capacitors (Best Student Paper Award) [8689-1]

H. Tang, H. A. Sodano, Univ. of Florida (United States)

868904 Analysis of the impedance resonance of piezoelectric multi-fiber composite stacks [8689-3]

S. Sherrit, A. Djrbashian, S. C. Bradford, Jet Propulsion Lab. (United States)

\section{SESSION 2 FERROELECTRIC MATERIALS}

868905 A quantum informed continuum model for ferroelectric and flexoelectric materials (Invited Paper) [8689-4]

W. S. Oates, Florida State Univ. (United States)

868906 Thermal and mechanical effects on large field dielectric loss in lanthanum-doped lead zirconate titanate [8689-5]

J. A. Gallagher, H. R. Jo, C. S. Lynch, Univ. of California, Los Angeles (United States)

868907 Coupled effects of hydrostatic pressure and bipolar electric field on the FE-AFE phase transformation in 95/5 PZT [8689-6]

J. C. Valadez, D. M. Pisani, C. S. Lynch, Univ. of California, Los Angeles (United States)

868908 Effects of compositional modification in lead lanthanum zirconate stannate titanate ceramics on electric energy storage properties [8689-7]

H. R. Jo, C. S. Lynch, Univ. of California, Los Angeles (United States)

\section{SESSION 3 SMART MATERIAL SYSTEMS}

8689 OA Lamb wave dispersion under finite plastic deformation [8689-9]

K. C. Liu, A. Ghoshal, U.S. Army Research Lab. (United States)

$8689 \mathrm{OB}$ Micromechanical analysis and finite element modeling of electromechanical properties of active piezoelectric structural fiber (PSF) composites [8689-10]

Q. Dai, K. Ng, Michigan Technological Univ. (United States)

8689 OC Feasibility study of shape control with zero applied voltage utilizing hysteresis in strainelectric field relationship of piezoelectric ceramics [8689-11]

T. Ikeda, T. Takahashi, Nagoya Univ. (Japan) 
8689 OD Nonlinear dynamics and thermodynamics of azobenzene polymer networks (Invited Paper) [8689-12]

W. S. Oates, J. Bin, Florida State Univ. (United States)

\section{SESSION $5 \quad$ ACTIVE POLYMERS II}

8689 OF Development of novel multifunctional biobased polymer composites with tailored conductive network of micro-and-nano-fillers [8689-14]

S. N. Leung, S. Ghaffari, H. E. Naguib, Univ. of Toronto (Canada)

8689 OG Network modeling of membrane-based artificial cellular systems [8689-15]

E. C. Freeman, M. K. Philen, D. J. Leo, Virginia Polytechnic Institute and State Univ. (United States)

$8689 \mathrm{OH} \quad$ Meso-decorated self-healing gels: network structure and properties [8689-16]

J. Gong, K. Sawamura, S. Igarashi, H. Furukawa, Yamagata Univ. (Japan)

$8689 \mathrm{Ol}$ Observation instrument of dynamic friction interface of gel engineering materials with polarized optical microscopic [8689-17]

N. Yamada, M. Wada, M. H. Kabir, J. Gong, H. Furukawa, Yamagata Univ. (Japan)

\section{SESSION 6 SHAPE MEMORY POLYMERS}

8689 0J Aging effects of epoxy shape memory polymers [8689-18]

K. Dasharathi, J. A. Shaw, Univ. of Michigan (United States)

8689 OK The shape memory effect in crosslinked polymers: effects of polymer chemistry and network architecture [8689-19]

J. D. Davidson, Y. Li, N. C. Goulbourne, Univ. of Michigan (United States)

8689 OL Modeling mechanical behavior of epoxy-shape memory polymers [8689-20]

J. Chen, L. Liu, F. Fei, Y. Wang, Y. Liu, J. Leng, Harbin Institute of Technology (China)

8689 OM A constitutive theory for shape memory polymers: coupling of small and large deformation [8689-21]

Q. Tan, L. Liu, Y. Liu, J. Leng, X. Yan, Harbin Institute of Technology (China); H. Wang, Harbin FRP Institute (China)

\section{SESSION 7 SHAPE MEMORY POLYMER COMPOSITES}

8689 OP Electro-mechanical performance of shape-memory nanocomposites with graphene/CNF nanopaper [8689-25]

H. Lu, T. Zheng, J. Wang, Harbin Institute of Technology (China)

$86890 Q$ Three dimensional experimental characterization of a NiMnGa alloy [8689-64]

I. Nelson, C. Ciocanel, D. LaMaster, H. Feigenbaum, Northern Arizona Univ. (United States) 
8689 OR Shape memory thermal lag and superelastic rate sensitivity of SMA cellular structures [8689-26]

R. T. Watkins, J. A. Shaw, Univ. of Michigan (United States); D. S. Grummon, Michigan State Univ. (United States)

8689 OS Fatigue properties of NiTi shape-memory alloy thin plates [8689-27]

H. Yamamoto, M. Taya, Y. Liang, O. C. Namli, Univ. of Washington (United States); M. Saito, Nabtesco Corp. (Japan)

8689 OT Experiments on functional fatigue of thermally activated shape memory alloy springs and correlations with driving force intensity [8689-28]

A. Rao, A. R. Srinivasa, Texas A\&M Univ. (United States)

\section{SESSION 9 MAGNETO-ACTIVE MATERIALS}

8689 OU Semi-empirical modeling of hysteresis compensation in magnetostrictive actuator [8689-30]

K.-H. Ji, STX Offshore \& Shipbuilding Co., Ltd. (Korea, Republic of); H.-J. Park, Chungnam National Univ. (Korea, Republic of); Y.-W. Park, Chungnam National Univ. (Korea, Republic of) and Univ. of Maryland (United States); N. M. Wereley, Univ. of Maryland (United States)

8689 OV Characterization and finite element modeling of Galfenol minor flux density loops [8689-31] Z. Deng, M. J. Dapino, The Ohio State Univ. (United States)

8689 OW Electrical resistivity and piezoresistivity of Ni-CNT filled epoxy-based composites [8689-32] J. Jiang, H. Xiao, H. Li, Harbin Institute of Technology (China)

\section{SESSION 10 SMA: MODELING AND CHARACTERIZATION I}

8689 0X A two species thermodynamic Preisach approach for simulating superelastic responses of shape memory alloys under tension and bending loading conditions [8689-33]

S. Doraiswamy, A. Rao, A. R. Srinivasa, Texas A\&M Univ. (United States)

8689 OZ Magnetization in MSMA: 2D modeling and experimental characterization [8689-35] D. H. LaMaster, H. P. Feigenbaum, I. D. Nelson, C. Ciocanel, Northern Arizona Univ. (United States)

868911 Thermal response of infinitely extended layered nickel-titanium shape memory alloy thin film with variable material properties [8689-37]

A. Bhattacharyya, M. M. Ozturk, Univ. of Arkansas at Little Rock (United States)

\section{SESSION 11 SMA: MODELING AND CHARACTERIZATION II}

868912 Sensing of retained martensite during thermal cycling of shape memory alloy wires via electrical resistance [8689-38]

C. B. Churchill, HRL Labs., LLC (United States) 
868913 Thermo-mechanical self-adaptive ball screw drive using thermal shape memory effect [8689-39]

I. Navarro y de Sosa, Chemnitz Univ. of Technology (Germany); A. Bucht, T. Junker, K. Pagel, W.-G. Drossel, Fraunhofer Institute for Machine Tools and Forming Technology (Germany)

868914 Assessing the morphology of selective laser melted NiTi-scaffolds for a three-dimensional quantification of the one-way shape memory effect [8689-40] T. Bormann, Univ. of Basel (Switzerland) and Univ. of Applied Sciences and Arts Northwestern Switzerland (Switzerland); M. de Wild, Univ. of Applied Sciences and Arts Northwestern Switzerland (Switzerland); F. Beckmann, Institute of Materials Research, Helmholtz Zentrum Geesthacht (Germany); B. Müller, Univ. of Basel (Switzerland)

868915 Lagoudas model for optomechanical mountings: parametric study and characterization campaign [8689-41]

D. Rigamonti, Istituto per l'Energetica e le Interfasi, CNR (Italy); F. Zanetti, CGS S.p.A. (Italy); M. Riva, I.N.A.F. - Osservatorio Astronomico di Brera (Italy); E. Villa, F. Passaretti, Istituto per I'Energetica e le Interfasi, CNR (Italy); F. M. Zerbi, I.N.A.F. - Osservatorio Astronomico di Brera (Italy)

\section{SESSION 12 ACTIVE COMPOSITES I}

868917 The challenges of achieving good electrical and mechanical properties when making structural supercapacitors [8689-43]

C. Ciocanel, C. Browder, C. Simpson, R. Colburn, Northern Arizona Univ. (United States)

868918 Nanowire-graphene hybrids for lithium-ion-battery [8689-44]

M. A. I. Shuvo, M. A. R. Khan, H. Karim, P. Morton, T. Wilson, M. Mendoza, Y. Lin, The Univ. of Texas at El Paso (United States)

\section{SESSION 13 MULTIFUNCTIONAL STRUCTURAL COMPOSITES}

868919 A finite element modeling of a multifunctional hybrid composite beam with viscoelastic materials [8689-46]

Y. Wang, D. J. Inman, Univ. of Michigan (United States)

8689 1A Acoustic impedance matching using dynamic homogenization of periodic composites [8689-47]

H. Sadeghi, A. Srivastava, S. Nemat-Nasser, Univ. of California, San Diego (United States)

8689 1B Modifying the acoustic impedance of polyurea-based composites [8689-48]

W. Nantasetphong, A. V. Amirkhizi, Z. Jia, S. Nemat-Nasser, Univ. of California, San Diego (United States)

8689 IC Ultrasonic studies of fly ash/polyurea composites [8689-49]

J. Qiao, Harbin Institute of Technology (China) and Univ. of California, San Diego (United States); A. V. Amirkhizi, S. Nemat-Nasser, Univ. of California, San Diego (United States);

G. Wu, Harbin Institute of Technology (China) 
8689 ID Comparative study of nanomaterials for interlaminar reinforcement of fiber-composite panels [8689-51]

K. R. Chiu, T. Duenas, NextGen Aeronautics, Inc. (United States); Y. Dzenis, J. Kaser, Precision Nanotechnologies, LLC (United States); C. E. Bakis, Pennsylvania State Univ. (United States); J. K. Roberts, D. Carter, U.S. Army Research, Development and Engineering Command (United States)

$8689 \mathrm{1H}$ Fatigue damage evaluation of plain woven carbon fiber reinforced plastic (CFRP) modified with MFC (micro-fibrillated cellulose) by thermo-elastic damage analysis (TDA) [8689-55] R. Aoyama, K. Okubo, T. Fujii, Doshisha Univ. (Japan)

868911 Computational design of multifunctional composites made of shape memory alloys and fiber reinforced plastics [8689-56]

B. Senf, C. Eppler, A. Bucht, Fraunhofer Institute for Machine Tools and Forming Technologies (Germany); I. Navarro y de Sosa, Chemnitz Univ. of Technology (Germany); H. Kunze, Fraunhofer Institute for Machine Tools and Forming Technologies (Germany)

$86891 \mathrm{~K}$ Phase transition of shape-memory effect in glassy shape-memory polymers [8689-58] H. Lu, Harbin Institute of Technology (China)

$8689 \mathrm{lL}$ Simulation and experiment research on smart metamaterial structures for wave isolation [8689-59]

Y. Li, Jiangsu Automation Research Institute (China); H. Sun, Jiangsu Automation Research Institute (China) and Nanjing Univ.of Science and Technology (China); Z. Li, Jiangsu Automation Research Institute (China)

8689 1M A study of damping characteristics of alumina-filled epoxy nano-composites [8689-60] P. Katiyar, A. Kumar, Harcourt Butler Technological Institute (India)

$86891 Q$ Interlaminar shear strength and thermo-mechanical properties of nano-enhanced composite materials under thermal shock [8689-45]

G. Gkikas, D.-D. Douka, N.-M. Barkoula, A. S. Paipetis, Univ. of loannina (Greece)

8689 IR Fabrication and characterization of shape memory polystyrene foams [8689-50]

Y. Yao, P. Xiang, J. Leng, Harbin Institute of Technology (China)

Author Index 
Proc. of SPIE Vol. $8689868901-8$

Downloaded From: https://www.spiedigitallibrary.org/conference-proceedings-of-spie on 26 Apr 2023 Terms of Use: https://www.spiedigitallibrary.org/terms-of-use 


\title{
Conference Committee
}

\author{
Symposium Chairs
}

Norbert Meyendorf, Fraunhofer-Institut für Zerstörungsfreie

Prüfverfahren (Germany) and University of Dayton (United States)

Norman Wereley, University of Maryland, College Park (United States)

\section{Symposium Cochairs}

Victor Giurgiutiu, University of South Carolina (United States)

Christopher S. Lynch, University of California, Los Angeles

(United States)

Conference Chair

Nakhiah C. Goulbourne, University of Michigan (United States)

Conference Cochair

Hani E. Naguib, University of Toronto (Canada)

Conference Program Committee

Abhijit Bhattacharyya, University of Arkansas at Little Rock (United States)

Gregory P. Carman, University of California, Los Angeles (United States)

Pavel M. Chaplya, Sandia National Laboratories (United States) Constantin Ciocanel, Northern Arizona University (United States) Marcelo J. Dapino, The Ohio State University (United States)

Sergio Luis dos Santos e Lucato, Teledyne Scientific Company (United States)

LeAnn E. Faidley, Wartburg College (United States)

Daniel J. Inman, University of Michigan (United States)

Marc Kamlah, Karlsruher Institut für Technologie (Germany)

Haluk E. Karaca, University of Kentucky (United States)

Ibrahim Karaman, Texas A\&M University (United States)

Kwang Jin Kim, University of Nevada, Reno (United States)

Dimitris C. Lagoudas, Texas A\&M University (United States)

Chad M. Landis, The University of Texas at Austin (United States)

Kam K. Leang, University of Nevada, Reno (United States)

Donald J. Leo, Virginia Polytechnic Institute and State University (United States)

Jiangyu Li, University of Washington (United States) 
Christopher S. Lynch, University of California, Los Angeles (United States)

Karla M. Mossi, Virginia Commonwealth University (United States)

Robert C. O'Handley, Massachusetts Institute of Technology (United States)

Etienne Patoor, Université Metz (France)

Ralph C. Smith, North Carolina State University (United States)

Jonghwan Suhr, University of Delaware (United States)

Vishnu Baba Sundaresan, Virginia Commonwealth University (United States)

\section{Session Chairs}

1 Piezoelectric Composites

Nakhiah C. Goulbourne, University of Michigan (United States)

Hani E. Naguib, University of Toronto (Canada)

2 Ferroelectric Materials

Henry A. Sodano, University of Florida (United States)

Hassene Ben Atitallah, The Pennsylvania State University (United States)

3 Smart Material Systems

Christopher S. Lynch, University of California, Los Angeles (United States)

William S. Oates, The Florida State University (United States)

4 Active Polymers I

Constantin Ciocanel, Northern Arizona University (United States)

Hani E. Naguib, University of Toronto (Canada)

5 Active Polymers II

Vishnu Baba Sundaresan, The Ohio State University (United States)

Andy Sarles, The University of Tennessee (United States)

6 Shape Memory Polymers

Donald J. Leo, Virginia Polytechnic Institute and State University (United States)

Arun R. Srinivasa, Texas A\&M University (United States)

7 Shape Memory Polymer Composites

Atsuhiko Senba, Nagoya University (Japan)

Kuang Liu, U.S. Army Research Laboratory (United States)

8 Shape Memory Alloys: Experimental

Veera Sundararaghavan, University of Michigan (United States)

Nakhiah C. Goulbourne, University of Michigan (United States) 
9 Magneto-Active Materials

Arun R. Srinivasa, Texas A\&M University (United States)

Nakhiah C. Goulbourne, University of Michigan (United States)

10 SMA: Modeling and Characterization I

Marcelo J. Dapino, The Ohio State University (United States)

Christopher B. Churchill, HRL Laboratories, LLC (United States)

11 SMA: Modeling and Characterization II

Nakhiah C. Goulbourne, University of Michigan (United States)

12 Active Composites I

Ralph C. Smith, North Carolina State University (United States)

Nakhiah C. Goulbourne, University of Michigan (United States)

Hani E. Naguib, University of Toronto (Canada)

13 Multifunctional Structural Composites

Constantin Ciocanel, Northern Arizona University (United States)

Hani E. Naguib, University of Toronto (Canada) 
Proc. of SPIE Vol. $8689868901-12$

Downloaded From: https://www.spiedigitallibrary.org/conference-proceedings-of-spie on 26 Apr 2023 Terms of Use: https://www.spiedigitallibrary.org/terms-of-use 